\title{
DEMOGRAPHIC ANALYSIS OF ACETABULAR FRACTURES TREATED IN A QUATERNARY CARE HOSPITAL FROM 2005 TO 2016
}

\author{
ANÁLISE DEMOGRÁFICA DAS FRATURAS DO ACETÁBULO TRATADAS \\ EM UM HOSPITAL QUATERNÁRIO DE 2005 A 2016
}

\author{
Marcelo Cortês Cavalcante, ${ }^{1}$ Frederico Augusto Alves de Arruda, ${ }^{1}$ Guilherme Boni, ${ }^{1}$ Gustavo Tadeu Sanchez, ${ }^{1}$ \\ DANIEL BALBACHEVSKY, ${ }^{1}$ FERNANDO BALDY DOS REIS ${ }^{1}$
}

1. Universidade Federal de São Paulo (UNIFESP), Escola Paulista de Medicina, São Paulo, SP, Brazil.

\begin{abstract}
Objective: Analyze the clinical and sociodemographic data on acetabular fractures in a Brazilian quaternary care hospital and compare with data reported in the literature. Methods: A descriptive, analytical cross-sectional epidemiological study analyzing 87 patients with acetabular fractures at Hospital São Paulo (UNIFESP/EPM) between 2005 and 2016. Demographic variables such as age, sex, occupation, educational level and color were investigated. Acetabular fractures were classified according to the AO/OTA group and Judet and Letournel classification. Therapeutic approach, hospital length of stay and waiting time for surgery as well as complications were analyzed. Associations were established among the various variables obtained. Results: The mean age of patients with acetabulum fractures was 39.8 years (SD 13.1 years). There was a predominance of posterior wall (34.5\%) and dual-column (14.9\%) fractures. The average hospital length of stay was 14.4 days. More than $90 \%$ of patients underwent a surgical procedure. One-fourth of patients had complications, the main one being infection (12.6\%). Conclusions: Unimodal age distribution was obtained with a predominance of white male economically active patients. There was a predominance of posterior wall fractures. More than $90 \%$ of patients underwent surgery before they had been in hospital for 14 days. A statistically significant association was found between complications and exceeded length of hospital stay. Level of evidence II, Retrospective study.
\end{abstract}

Keywords: Analysis. Acetabulum. Fractures, Bone. Wounds/ complications.

\section{RESUMO}

Objetivo: Analisar os dados clínicos e sociodemográficos das fraturas acetabulares em um hospital quaternário brasileiro e comparar com dados relatados na literatura. Métodos: Estudo epidemiológico, descritivo, analítico transversal, em que foram analisados 87 pacientes com fraturas acetabulares no Hospital São Paulo (UNIFESP/EPM) entre 2005 e 2016. Variáveis demográficas como idade, sexo, profissão, escolaridade e cor foram pesquisadas. As fraturas acetabulares foram classificadas conforme o grupo AO/OTA e conforme Judet e Letournel. A terapêutica, o tempo de internação e de espera para cirurgia bem como as complicações foram analisadas. Foram feitas associações entre as diversas variáveis obtidas. Resultados: A média de idade dos pacientes vítimas de fraturas do acetábulo foi de 39,8 anos (DP 13,1 anos). Houve predomínio das fraturas da parede posterior (34,5\%) e dupla coluna (14,9\%). Os pacientes ficaram, em média, 14,4 dias internados. Mais de 90\% dos pacientes foram submetidos à abordagem cirúrgica. Um quarto dos pacientes tiveram complicações, sendo a principal, infecção (12,6\%). Conclusões: Foi obtida uma amostra etária unimodal com predomínio de pacientes do sexo masculino, brancos e economicamente ativos. Houve um predomínio das fraturas da parede posterior. Mais de $90 \%$ dos pacientes foram operados antes dos 14 dias de internação. Constatou-se uma associação estatisticamente significante entre complicações e tempo excedido de permanência hospitalar. Nível de evidência II, Estudo retrospectivo.

Descritores: Análise. Acetábulo. Fraturas ósseas. Lesões/ complicações.

Citation: Cavalcante MC, Arruda FAA, Boni G, Sanchez GT, Balbachevsky D, Reis FB. Comparison of LCP and intramedullary nail osteosynthesis in calcaneal fractures. Acta Ortop Bras. [online]. 2019;27(6):317-20. Available from URL: http://www.scielo.br/aob.

\section{INTRODUCTION}

Acetabular fractures are uncommon and are usually the result of high-energy trauma. ${ }^{1,2,3}$ Road accidents constitute the main cause of these injuries, which represent a major orthopedic challenge. ${ }^{4}$ In this scenario, there is considerable associated morbidity, dictating prolonged periods of absence from work and a heavy burden on the health system and the community.

Over the past few decades, there has been an important shift from non-surgical to surgical treatment, as evidenced by the work of Judet \& Letournel, who have achieved good results through the surgical

All authors declare no potential conflict of interest related to this article.

Work conducted at the Traumatology Division, Department of Orthopedics and Traumatology, Universidade Federal de São Paulo (UNIFESP), São Paulo, SP, Brazil. Correspondence: Marcelo Cortês Cavalcante. Rua Joaquim Távora, 1020, apartamento 92B, Vila Mariana, São Paulo, SP, Brazil. marcelo_cortes88@hotmail.com 
treatment of these fractures and defined open reduction and internal fixation as the gold standard treatment for displaced fractures. ${ }^{3}$ Encouraged by these results, other authors (Matta, Tile) ${ }^{5}$ started case series in an attempt to reproduce the reduction quality and outcome, which despite representing a technical challenge to the surgeon and presenting a long learning curve, confirmed superiority when compared to the outcome of conservatively treated cases. The aim of this study is to describe the clinical and sociodemographic characteristics of patients with acetabular fractures treated at a quaternary care university hospital.

\section{MATERIALS AND METHODS}

This is a descriptive, retrospective, analytical cross-sectional study. The participants are patients treated by the Trauma Group of the Department of Orthopedics and Traumatology of the Universidade Federal de São Paulo (DOT-UNIFESP/EPM), who presented with acetabulum fracture and were admitted to Hospital São Paulo between 2005 and 2016. The study was designed according to the Brazilian Standards for Human Subject Research, and its design was submitted and approved by the Institutional Review Board of Hospital São Paulo - Unifesp (CAAE [Certificate of Application for Ethical Review]: 62369616.0.0000.5505).

We included 89 patients admitted to Hospital São Paulo, men and women aged over 16 years with acetabulum fractures. Exclusion criteria were: ineligible medical records, unclear diagnosis, patients without clinical data and the patient's own refusal to participate in the study, by not signing the ICF (Informed Consent Form).

The physical and electronic medical records of the patients were analyzed during the screening period. Demographic variables such as age, sex, occupation, level of education and color were investigated. Acetabular fractures were classified according to the AO/OTA and Judet \& Letournel classifications by two independent observers. Hospital length of stay and waiting time for surgery were also analyzed. Therapy was instituted as per protocol and the patient management guidelines established by the Trauma Division of UNIFESP/EPM and reviewed by the teaching staff. Complications arising from the injuries or inherent to the treatment were analyzed. Finally, associations were established among the various variables obtained in order to find any causal relationship of the analyzed variables. Excel 2016 and the statistical software SPSS 2016 were used for the descriptive data analysis, applying the Chi-Square Test and Fischer's Exact Test when necessary. We considered $p<0.05$ for statistical significance.

\section{RESULTS}

Eighty-nine patients with acetabular fracture were admitted, but 2 patients were excluded from the analysis due to insufficient data in their medical records, and only 87 patients were used.

The mean age of patients with acetabulum fractures was 39.8 years (SD 13.1 years). The youngest patient was 20 years old and the oldest was 82 . Of the total sample of 87 patients, 75 were male, resulting in $86.2 \%$. Approximately half of the patients declared themselves white $(54 \%)$, followed by mixed-race $(41.4 \%)$ and black (4.6\%). Eighty-one percent of patients declared themselves economically active. With regard to level of education, $25.3 \%$ had completed high school and only $3.4 \%$ were illiterate. (Figure 1)

There was a slight predominance of right-sided fractures (51.7\%). In terms of fracture classification, $56.3 \%$ had associated fractures and $43.7 \%$ had fractures with an elementary pattern, according to the Judet and Letournel classification. Moreover, there was a predominance of posterior wall (34.5\%) and double column (14.9\%) fractures. The fractures were also classified by AO/OTA. (Table 1 and 2)

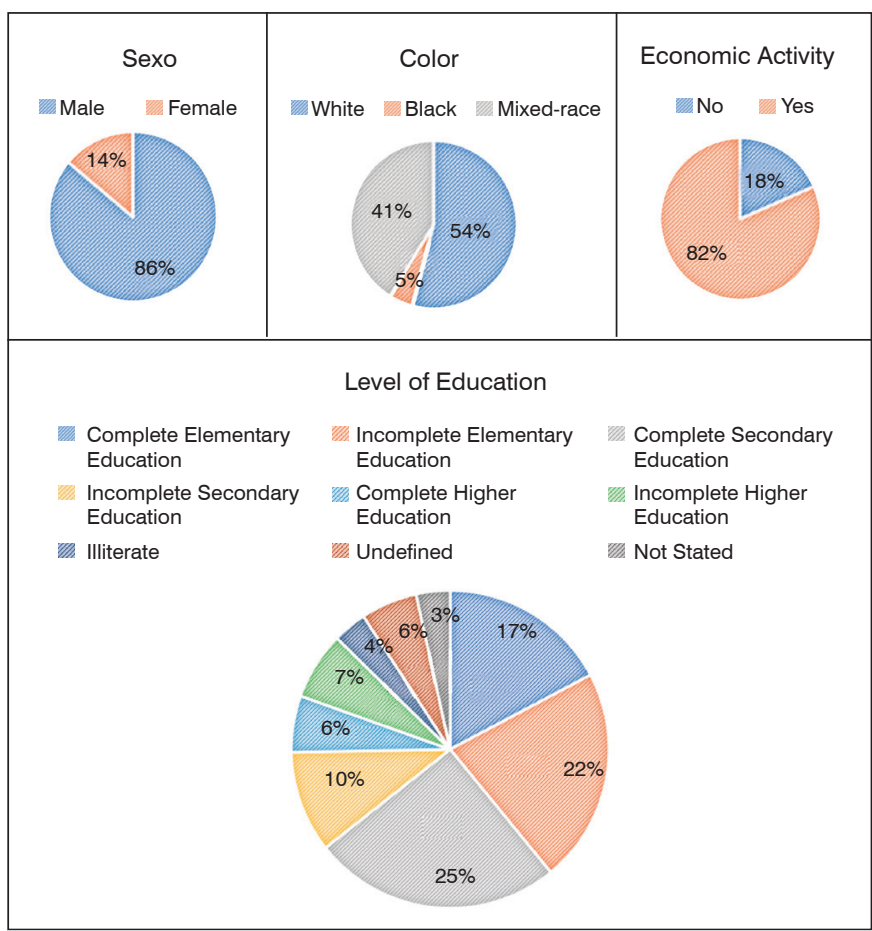

Figure 1. Description of the sociodemographic data of the 87 patients.

Table 1. Description of the acetabular fractures according to the Judet \& Letournel classification.

\begin{tabular}{c|c|c}
\hline & Frequency & Percentage (\%) \\
\hline Anterior column & 2 & 2.3 \\
\hline Posterior column & 3 & 3.4 \\
\hline Posterior wall & 30 & 34.5 \\
\hline Transverse & 4 & 4.6 \\
\hline $\begin{array}{c}\text { Anterior column + posterior } \\
\text { hemitransverse }\end{array}$ & 7 & 8.0 \\
\hline $\begin{array}{c}\text { Posterior column } \\
\text { +posterior wall, t-shaped }\end{array}$ & 6 & 6.9 \\
\hline T-shaped & 8 & 9.2 \\
\hline Posterior wall & 1 & 1.1 \\
\hline $\begin{array}{c}\text { Anterior wall + posterior } \\
\text { hemitransverse }\end{array}$ & 2 & 2.3 \\
\hline Transverse + posterior wall & 11 & 12.6 \\
\hline Dual column & 13 & 14.9 \\
\hline
\end{tabular}

Table 2. Description of the acetabular fractures according to the $\mathrm{AO} /$ OTA classification.

\begin{tabular}{c|c|c}
\hline & Frequency & Percentage (\%) \\
\hline A1 & 30 & 34.5 \\
\hline A2 & 3 & 3.4 \\
\hline A3 & 2 & 2.3 \\
\hline B1 & 19 & 21.8 \\
\hline B2 & 8 & 9.2 \\
\hline B3 & 12 & 13.8 \\
\hline C1 & 11 & 12.6 \\
\hline C2 & 1 & 1.1 \\
\hline C3 & 1 & 1.1 \\
\hline
\end{tabular}


Patients had a length of hospital stay averaging 14.4 days (SD 13.9), with a minimum period of 1 day and a maximum of 85 days. Of these, 50.6\% stayed for more than 10 days at Hospital São Paulo. Of the total patients, 93.5\% underwent surgery before they had been in hospital for 14 days, while $6.5 \%$ only had surgery later.

Seventy-nine patients (90.8\%) underwent surgical treatment and 8 (9.2\%) received conservative treatment. Of the total, 4 patients underwent percutaneous surgery, representing $4.6 \%$ of the sample. Most patients were operated on using a posterior approach (62.02\%), followed by the anterior (26.51\%) and combined (6.2\%) approaches. (Table 3)

Forty-six percent (46\%) of patients presented with complications. More than 30 associated injuries were documented, mainly consisting of pelvic ring injuries (9.2\%), tibia fractures (6.8\%), proximal femoral fractures (6.8\%) and traumatic brain injuries (5.74\%). Twenty-two patients (25.3\%) had complications resulting from their injuries or inherent to the treatment, the main ones being infection (12.64\%), peripheral nerve injury (4.59\%), and heterotopic ossification (3.44\%). Associations were also established between several variables. Of all 22 patients with complications, 40.9\% were found to have no associated fractures while $59.1 \%$ had them $(p=0.069)$. (Table 4 ) Seventeen of these patients $(77.3 \%)$ had a length of hospital stay greater than 10 days while for $5(22.7 \%)$ their hospital stay did not exceed this period ( $p=0.004)$. Therefore, there was statistical significance between the association of complications with exceeded length of hospital stay. (Table 5)

\begin{tabular}{|c|c|c|}
\hline & Frequency & Percentage (\%) \\
\hline $\begin{array}{c}\text { llioinguinal + Kocher } \\
\text { Langenbeck }\end{array}$ & 1 & 1.2 \\
\hline |lioinguinal & 17 & 21.51 \\
\hline Kocher Langenbeck & 49 & 62.02 \\
\hline $\begin{array}{c}\text { Kocher Langenbeck } \\
\text { + Pfannenstiel }\end{array}$ & 2 & 2.5 \\
\hline $\begin{array}{c}\text { Kocher Langenbeck } \\
+ \text { Stoppa }\end{array}$ & 2 & 2.5 \\
\hline Stoppa & 2 & 2.5 \\
\hline $\begin{array}{c}\text { Stoppa }+1 \text { st } \\
\text { llioinguinal window }\end{array}$ & 2 & 2.5 \\
\hline percutaneous & 4 & 5.0 \\
\hline
\end{tabular}

Table 4. Association between associated fractures $X$ complications.

\begin{tabular}{c|c|c|c|c}
\hline & & \multicolumn{2}{|c|}{ Complications } & \multirow{2}{*}{ Total } \\
\hline & & No & Yes & \\
\hline \multirow{3}{*}{ Associated Fractures } & \multirow{2}{*}{ No } & 41 & 9 & 50 \\
\cline { 3 - 5 } & & $63.1 \%$ & $40.9 \%$ & $57.5 \%$ \\
\cline { 2 - 5 } & \multirow{2}{*}{ Yes } & 24 & 13 & 37 \\
\cline { 3 - 5 } & & $36.9 \%$ & $59.1 \%$ & $42.4 \%$ \\
\hline \multirow{2}{*}{ Total } & 65 & 22 & 87 \\
\cline { 3 - 5 } & & $100.0 \%$ & $100.02 \%$ & $100.0 \%$ \\
\hline
\end{tabular}

Table 5. Association between length of hospital stay greater than 10 days $X$ complications.

\begin{tabular}{|c|c|c|c|c|}
\hline & & \multicolumn{2}{|c|}{ Complications } & \multirow{2}{*}{ Total } \\
\hline & & No & Yes & \\
\hline \multirow{4}{*}{$\begin{array}{l}\text { Length of Hospital Stay } \\
\qquad>10 \text { days }\end{array}$} & \multirow{2}{*}{ No } & 38 & 5 & 43 \\
\hline & & $58.5 \%$ & $22.7 \%$ & $49.4 \%$ \\
\hline & \multirow{2}{*}{ Yes } & 27 & 17 & 44 \\
\hline & & $41.5 \%$ & $77.3 \%$ & $50.6 \%$ \\
\hline \multirow{2}{*}{\multicolumn{2}{|c|}{ Total }} & 65 & 22 & 87 \\
\hline & & $100.0 \%$ & $100.0 \%$ & $100.0 \%$ \\
\hline
\end{tabular}

\section{DISCUSSION}

Epidemiological studies that represent the profile of certain fractures are still rare in Brazil, especially those that represent uncommon fractures, such as acetabular fractures. This study seeks to overcome this deficiency by providing an overview of a quaternary care hospital in the most densely populated city in the country.

The average age of the sample group of 39.85 years is similar to that reported by Ahmed et al., ${ }^{6}$ Dias et al. ${ }^{7}$ and Mauffrey et al. ${ }^{8}$ Acetabular fractures have a bimodal distribution, affecting at one extreme young and active patients who have sustained high-energy trauma. At the other extreme we find elderly patients who have sustained low-energy trauma. ${ }^{9}$ This pattern is more prevalent in developed countries than in developing countries, which tend to have a unimodal age distribution. A study conducted by Mauffrey et al. ${ }^{8}$ in 2014 draws this parallel between the US and China. The data obtained in our sample indicate a distribution with characteristics that more closely resemble those of the Chinese population.

The proportion of men was within the average range of the national and international literature, around 3 men to every woman. ${ }^{8}$ In our sample, $81 \%$ of patients declared themselves economically active. This data is extremely important because the requisite study, management and treatment of this fracture reduces the economic burden, allowing the subject to resume their professional duties as soon as possible.

Mauffrey et al., ${ }^{8}$ in their epidemiological comparative study of 661 Chinese and 212 North American subjects, discovered that $30-32 \%$ had posterior wall fractures and $17-21 \%$ dual-column fractures, according to the Judet and Letournel classification. These data closely resemble those found in our study with $34.5 \%$ and $14.9 \%$, respectively.

The average length of hospital stay of the 87 patients was 14.4 days, which closely resembles that reported in the study by Boudissa et al., ${ }^{10}$ in which 414 patients were studied in France. Conversely, in the work conducted by Laird ${ }^{2}$ with 351 patients in Scotland, the hospital stay was 24 days on average. Matta et al. ${ }^{10}$ reported that fractures older than 14 days entailed impaired reduction quality due to surgical difficulty. Based on this assumption, we found that $93.5 \%$ of the HSP patients underwent surgery before this critical period. Of the 87 patients studied, $46 \%$ had associated injuries, with more than 30 lesions characterized in this case. This denotes the importance of treating these patients and the difficulty involved. A quarter of the studied sample had some kind of complication, of which the most relevant was infection (12.6\%). In the study by Laird et al., ${ }^{2}$ $6.5 \%$ of the operated patients developed this complication, almost half of the value obtained in our study.

We observed statistical significance in the association between longer hospital stay and higher incidence of complications. However, there was no significance between higher number of associated fractures and complications.

As limitations of this study we can emphasize that it is a retrospective study with a small sample group in comparison to international studies, and that it was not possible to analyze important late complications, such as osteoarthritis, present in $26.6 \%$ of patients in the study by Giannoudis et al. ${ }^{11}$ However, even with these limitations, important data from our university hospital were imparted and compared with different populations, allowing a reflexive analysis of acetabular fractures.

\section{CONCLUSION}

A unimodal age distribution sample was obtained with economically active white male patients with a mean age of 39.85 years predominating. There was a predominance of posterior wall fractures followed by 
dual-column fractures, which is consistent with data from national and international literature. More than $90 \%$ of patients underwent surgery less than 14 days after admission, and the posterior surgical approach predominated.
A quarter of the patients had complications, the most prevalent of which was infection.

A statistically significant association was found between complications and exceeded length of hospital stay.

AUTHORS' CONTRIBUTIONS: Each author made significant individual contributions to this manuscript: MCC (0000-0003-1207-9185)*: data collection, data tabulation, writing of the article; FAAA (0000-0002-7647-3344)*: data collection, data tabulation, writing of the article; GB (0000-0002-4846-9188)*: statistical analysis, data review, article review; GTS (0000-0001-9732-8763)*: statistical analysis, data review, article review; DB (0000-0003-4955-5317)*: data collection, data tabulation, data review, article review; FBR (0000-0003-2431-2634)*: data review, article review, intellectual concept of the article and creation of the entire research project. *ORCID (Open Researcher and Contributor ID).

\section{REFERENCES}

1. Alonso JE, Volgas DA, Giordano V, Stannard JP. A review of the treatment of hip dislocations associated with acetabular fractures. Clin Orthop Relat Res. 2000;(377):32-43.

2. Laird A, Keating J. Acetabular fractures: a 16-year prospective epidemiologica study. J Bone Joint Surg Br. 2005;87(7):969-73

3. Letournel E. Acetabulum fractures: classification and management. Clin Orthop Relat Res. 1980;(151):81-106.

4. Al-Qahtani S, O'Connor G. Acetabular fractures before and after the introduction of seatbelt legislation. Can J Surg. 1996;39(4):317-20.

5. Tile M. Pelvic fractures: operative versus nonoperative treatment. Orthop Clin North Am. 1980;11(3):423-64.

6. Ahmed M, Abuodeh Y, Alhammoud A, Salameh M, Hasan K, Ahmed G. Epidemiology of acetabular fractures in Qatar. Int Orthop. 2018;42(9):2211-7.

7. Dias MV, Goldsztajn F, Guimarães JM, Grizendi JA, Correia M, Rocha TH
The epidemiology of acetabulum fractures treated at Instituto Nacional De Traumatologia E Ortopedia. Rev Bras Ortop. 2015;45(5):474-7.

8. Mauffrey C, Hao J, Cuellar DO 3rd, Herbert B, Chen X, Liu B, et al. The epidemiology and injury patterns of acetabular fractures: are the USA and China comparable? Clin Orthop Relat Res. 2014;472(11):3332-7.

9. Ferguson TA, Patel R, Bhandari M, Matta JM. Fractures of the acetabulum in patients aged 60 years and older: an epidemiological and radiological study. J Bone Joint Surg Br. 2010;92(2):250-7.

10. Matta JM, Anderson LM, Epstein HC, Hendricks P. Fractures of the acetabulum. A retrospective analysis. Clin Orthop Relat Res. 1986;(205):230-40.

11. Giannoudis PV, Grotz MRW, Papakostidis C, Dinopoulos H. Operative treatment of displaced fractures of the acetabulum: a meta-analysis. J Bone Joint Surg Br. 2005;87(1):2-9. 